\title{
Chronic Levodopa and Renal Function
}

\author{
MARGARET M. HOEHN
}

SUMMARY: Renal function studies were performed in seventeen patients, under metabolic ward conditions, before the initiation of therapy with levodopa. These studies were repeated during the first two to three weeks of treatment and, again. after one to two years of chronic therapy. There were no significant differences between the results of pre- and posttherapy studies, except that the blood urea nitrogen was slighlly, but significantly, elevated in the nine patients who had been on the drug for one to two years. During the early weeks of treatment, there was an

RÉSUMÉ: Nous avons étudié la fonction rénale, sous condition d'Unité Métabolique, chez 17 patients parkinsoniens devant recevoir la levodopa. Ces études furent répétées au cours des deur ou trois premières semaines du traitement et de nouveau après un ou deux ans de traitement chronique. 'Il n'y eut aucune différence significative sauf une légère élévation de l'urée (BUN) chez 9 patients traités pour un ou deux ans. Au début du traitement il y eut tendance à l'hypoten- insignificant trend towards hypotension and increased excretion of sodium. This did not persist in those patients followed for one to two years after the initiation of treatment. Glomerular filtration rate, as measured by an endogenous method, was unchanged by chronic therapy with levodopa. These results are in contrast to the acutely increased glomerular filtration rate, as measured by an exogenous method, and the increased sodium excretion following a single dose of levodopa or dopamine.

sion et à l'augmentation de l'excrétion du sodium. Ceci ne devait pas persister après un ou deux ans. Le traitement chronique à la levodopa ne modifie aucunement le taux de filtration glomérulaire, tel que mesuré par la méthode endogène. Ces résultats diffèrent de ceux obtenus après une dose simple de levodopa ou de dópamine où lon vote un taux de filtration glomérulaire augmenté, tel que mesuré par une méthode exogène, et une augmentation de l'excrétion sodée.

\section{INTRODUCTION}

Dopamine (DA) has been demonstrated to cause renal, mesenteric, and coeliac vasodilation (Eble, 1964; Goldberg and Whitsett, 1971; McDonald et al, 1964; McNay et al, 1966; Meyer et al, 1967), increased renal plasma flow and glomerular filtration rate (GFR) (Meyer et al, 1967), and markedly increased sodium excretion (Finley et al, 1970, 1971; Goldberg et al, 1963; McDonald et al, 1964). These results have been obtained during the hours following a single dose of DA ordopa. During the early weeks of treatment with levodopa, milder (and, in two patients, transient) natriuretic effects of levodopa were demonstrated in three of four patients on constant sodium diets (Katz and Hoehn, 1977). The natriuresis was unaccompanied by significant changes in the renin-aldosterone system and did not result in hypotension. Because of the extensive use of levodopa in the treatment of Parkinsonism, the present study was undertaken to determine whether the drug also alters renal function during chronic administration over several years.

\section{PATIENTS AND METHODS}

Seventeen patients were studied before starting treatment with levodopa and $15 \pm 6.4$ days after starting levodopa, when the average dosage was $3.0 \pm$ SE $0.69 \mathrm{gm}$ daily. Nine of these patients again were studied one to two years after continuous therapy with levodopa, when the dosage was $5.375 \pm$ SE $1.4 \mathrm{gm}$ daily. There were eight men and nine women. The average age before starting treatment was $64.2 \pm \mathrm{SE} 10.7$ years. Fifteen patients had Parkinsonism, one patient had the rigid form of Huntington's disease, and one patient had diffuse cerebral atrophy, with tremor 
and clumsiness. The fifteen patients with Parkinsonism had had their disease for 12.6 \pm SE 9 years. By a system of grading based on a maximum score of 100 for the most severe neurologic deficit, the Parkinsonian patients had a mean score of $45.8 \pm$ 14.1. None had hypertension, congestive heart failure, peripheral vascular disease, a history of coronary insufficiency or myocardial infarction, or hepatic or renal disease. None had received anticholinergic drugs for at least a week before the study; seven had received levodopa three weeks to three years before entering the study.

Patients were admitted to the airconditioned clinical research unit. They received a self-selected, catecholamine-free, constant diet, containing $60-146 \mathrm{mEq}$ sodium and $63-104$ $\mathrm{mEq}$ potassium daily. Level of activity was approximately the same for all. Blood pressure and heart rate were determined three times a day. At the end of the drug-free stabilization period, a 24-hour collection of urine was started at 6 a.m., with blood drawn at the beginning of the collection period, while the patient was fasting and supine. Treatment with levodopa was started the next day and increased to an average daily dosage of $3.0 \pm$ SE $0.69 \mathrm{gm}$ over a mean of $15 \pm$ 6.4 days while the patient was still in the hospital. The studies were then repeated. Nine of these patients were readmitted to hospital one to two years after starting therapy with levodopa, when the mean daily dosage was 5.375 $\pm \mathrm{SE} 1.4 \mathrm{gm}$, and the studies were repeated under identical conditions. No patients had developed additional systemic disease during the interval. No patients suffered diarrhea or vomiting during the studies.

Blood urea nitrogen (BUN), electrolytes, and creatinine, as well as 24hour urine volume and creatinine, sodium, and potassium excretion, were determined for each study period. Creatinine was measured by the Jaffe method on a Technicon Auto Analyzer. The paired $t$-test was used for statistical analyses.

\section{RESULTS}

Although some patients developed mild and transient postural hypo- tension, there were no significant differences in blood pressure before and during treatment. Mean supine and upright blood pressures were as follows: before treatment: $122 / 80$ and $116 / 77$; after treatment for two to three weeks, at a daily dosage of levodopa of approximately $3.0 \mathrm{gm}$ : $117 / 77$ and 109/73; after one to two years of treatment, at a daily dosage of approximately $5.0 \mathrm{gm:} 126 / 78$ and $114 / 76$. There was a slight trend toward hypotension during the initiation of treatment. There were no consistent changes in heart rate, and no patients developed cardiac arrhythmias.

The values for BUN, serum sodium, serum potassium, and creatinine clearance before and during chronic therapy with levodopa are given in Table 1. There are no significant differences at the $p<.05$ level except that the BUN increased in the nine patients studied before and after treatment for one to two years from a pretreatment mean of $17.2 \pm$ SE 3.3 to $21.3 \pm \mathrm{SE} 4.1 \mathrm{mg} \%$.

Although there was an insignificant trend toward increased sodium excretion during the first two to three weeks of treatment, there was no indication of increased sodium excretion in patients who had been receiving levodopa for two to three years (Table 1). Sodium excretion was as follows: before and after treatment with approximately $3.0 \mathrm{gm}$ levodopa daily for two to three weeks: $82.0 \pm$ SE 47.1 and $100.4 \pm \mathrm{SE} 46.9 \mathrm{mEq} / 24$-hour total urine; before and after treatment with approximately $5.0 \mathrm{gm}$ levodopa daily for one to two years: $80.0 \pm \mathrm{SE}$ 47.5 and $82.9 \pm \mathrm{SE} 42.1 \mathrm{mEq} / 24$-hour total urine volume. Sodium clearances were as follows: before and after two to three weeks of treatment with levodopa: $0.39 \pm$ SE 0.29 and $0.36 \pm$ SE $0.2 \mathrm{ml} /$ minute; before and after one to two years of treatment with levodopa: $0.43 \pm \mathrm{SE} 0.23$ and $0.48 \pm \mathrm{SE} 0.2 \mathrm{ml} /$ minute. There was no consistent effect of levodopa on potassium excretion. Patients who had mild hypotension during the early weeks of treatment were not consistently those who had slight natriuresis.

\section{DISCUSSION}

Most studies of the effects of DA or levodopa on renal function have been concerned with the acute effects of a single dose. Immediately after the intravenous infusion of DA in dogs, renal and mesenteric vasodilation occurs, with increased renal blood flow (Elbe, 1964; Meyer et al, 1967; McNay et al, 1965, 1966), increased urine volume, and increased excretion of sodium and potassium (Davis et al, 1968; Meyer et al, 1967). Increased paraaminohippurate and inulin clearances have also been demonstrated (Meyer et al, 1967). Similar acute results have been obtained after intravenous DA in normal humans and in patients with congestive heart failure (Finlay et al, 1971; Gold berg et al, 1963; Gold berg and Whitsett, 1970; McDonald et al, 1964), and after a single oral dose of levodopa in Parkinsonian patients (Finlay et al, 1970, 1971; Goldberg et al, 1963; Katz and Hoehn, 1977). This response to a single dose occurs in both dopa-naive patients and in patients on chronic therapy with levodopa, in contrast to the development of tolerance to the cardiac effect of shortening of the preinjection period (Finley et al, 1970, 1971; Katz and Hoehn, 1977; McDonald et al, 1964; Whitsett et al, 1970).

Renal vasodilation probably is due to a direct action of DA on specific dopaminergic receptors (McNay et al, 1965; Meyer et al, 1967). Bell and Lang (1973), experimenting in dogs, concluded that electrical stimulation of the midbrain regions activates nerves subserving the renal vasculature which release DA as a neurotransmitter. The activation caused $10-30 \%$ increases in renal blood flow, which were comparable to those obtained by aortic injection of DA. The cause of the natriuresis is unknown. It has been attributed to increased GFR (Finlay et al, 1970, 1971; Goldberg et al, 1963; Meyer et al, 1967). However, after intravenous infusions of DA in dogs, Davis et al (1968) found no change in either GFR or in fractional sodium reabsorption by the proximal tubule; they postulated that the increased sodium excretion probably was a direct or indirect tubule effect at a site distal to the proximal tubule. In addition, there may be species differences, since Needleman et al (1974) 
TABLE I

$B U N$, Serum Na and K. Sodium Excretion, and Creatinine and Sodium Clearance Before and During Levodopa Therapy*

\begin{tabular}{|c|c|c|c|c|}
\hline & $\begin{array}{c}\text { Before } \\
\text { Treatment }\end{array}$ & $\begin{array}{l}\text { After } 15 \text { Days } \\
\text { Treatment }\end{array}$ & $\begin{array}{c}\text { Before } \\
\text { Treatment }\end{array}$ & $\begin{array}{l}\text { After } 1-2 \text { Yrs. } \\
\text { Treatment }\end{array}$ \\
\hline & \multicolumn{2}{|c|}{17 Patients } & \multicolumn{2}{|c|}{9 Patients } \\
\hline $\begin{array}{l}\text { BLOOD UREA NITROGEN } \\
\text { (normal: } 10-20 \mathrm{mg} \% \text { ) }\end{array}$ & $16.1 \pm 5.3$ & $17.7 \pm 3.7$ & $17.2 \pm 3.3^{* * *}$ & $21.3 \pm 4.1: \because$ \\
\hline $\begin{array}{l}\text { SERUM SODIUM } \\
\quad(\text { normal: } 134-145 \mathrm{mEq} / \mathrm{L})\end{array}$ & $141.0 \pm 2.7$ & $140.3 \pm 2.8$ & $140.7 \pm 1.9$ & $142.1 \pm 2.5$ \\
\hline $\begin{array}{l}\text { SERUM POTASSIUM } \\
\text { (normal: } 3.0-5.5 \mathrm{mEq} / \mathrm{L} \text { ) }\end{array}$ & $4.2 \pm 0.3$ & $4.2 \pm 0.3$ & $4.2 \pm 0.2$ & $4.5 \pm 0.2$ \\
\hline $\begin{array}{l}\text { SODIUM EXCRETION } \\
\text { (mEq/TV-24 hours) }\end{array}$ & $82.0 \pm 47.1$ & $100.4 \pm 46.9$ & $80.0 \pm 47.5$ & $82.9 \pm 42.1$ \\
\hline $\begin{array}{l}\text { SODIUM CLEARANCE } \\
(\mathrm{ml} / \mathrm{min})\end{array}$ & $0.39 \pm 0.29$ & $0.36 \pm 0.2$ & $0.43 \pm 0.23$ & $0.48 \pm 0.2$ \\
\hline $\begin{array}{l}\text { CREATININE CLEARANCE } \\
(\mathrm{ml} / \mathrm{min})\end{array}$ & $70.0 \pm 27.9$ & $77.2 \pm 29.9$ & $70.1 \pm 28.7$ & $79.1 \pm 27.5$ \\
\hline
\end{tabular}

* Values given as mean \pm S.E.M.

** Studies conducted after treatment for $15 \pm 6.4$ days, when the mean dosage of levodopa was $3.0 \pm 0.69$ grams daily.

*** Studies conducted after treatment for $1-2$ years, when the mean dosage of levodopa was $5.375 \pm 1.4$ grams daily.

*** $p=<.05$. All other differences are not significant.

administered DA to isolated perfused rabbit kidney and produced renal vasoconstriction.

In contrast to the acute effects of a single dose of levodopa or DA, the present study investigated the effects of chronic therapy with levodopa on certain tests of renal function. The slightly increased BUN observed in patients after one to two years of treatment may reflect the increasing age of the patients. In the Eaton collaborative study (Keenan, 1970), the BUN was elevated in 61 of the 585 patients on whom this test was performed. None was significantly abnormal, and all abnormal values were either transient or unchanged from control readings. Although the GFR, as measured by an exogenous clearance method, has been demonstrated to be increased acutely by a single dose of levodopa (Finlay et al, 1970, 1971; Goldberg et al., 1963; Meyer et al, 1967), there was no indication from the present studies that chronic therapy with levodopa alters the GFR, as assessed by the clearance of endogenous creatinine. Similarly, the clearance of sodium was not altered by chronic levodopa. There was some evidence, both from this study and previous ones (Katz and Hoehn, 1977), that any natriuretic response was confined to the early period of chronic treatment, when orthostatic hypotension was also most troublesome. It is possible that tolerance to the effects of levodopa on the GFR and tubular reabsorption develops during prolonged treatment or that the acute effects of each single dose last only a few hours, with subsequent equalizing effects producing no overall change in renal clearance over a 24-hour period.

Patients with Parkinson's disease have been reported to have plasma renin activity (PRA) levels which were low both in recumbancy and the erect posture (Barbeau et al, 1969; Michelakis and Robertson, 1970), or only in response to postural stimuli (Rappeli et al, 1978). Treatment of these patients with levodopa produced an additional decrease of PRA levels in one study (Barbeau et al, 1969); improvement of orthostatic values to normal levels in another study (Michelakis and Robertson, 1970); and insignificant or infrequent effects on PRA levels in others (Katz and Hoehn,
1977; Rappelli et al, 1978). Although low levels of aldosterone secretion have been reported in untreated patients with Parkinsonism (Barbeau et al, 1969), normal aldosterone secretion has been reported in most patients during levodopa therapy (Katz and Hoehn, 1977; Sullivan et al, 1973).

In no patients in the present study was orthostatic hypotension associated with increased sodium excretion. It previously has been pointed out (Katz and Hoehn, 1977) that normal levels of renin and aldosterone might be inappropriately low in the early stages of levodopa treatment, when there may be mild natriuresis. However, there is no convincing evidence that changes in renal function, sodium excretion, or the renin-aldosterone system are responsible for the orthostatic hypotension of Parkinsonian patients treated for long periods of time with levodopa.

\section{ACKNOWLEDGEMENTS}

Appreciation is expressed to Fred Katz, MD, Miss Linda Greco-Sanders and the staff of the Clinical Research Center. University of Colorado Health Sciences Center, for their advice, help, and cooperation. The levodopa (Larodopa) received by the patients 
was supplied by Hoffman-LaRoche. Nutley, New Jersey. This work was supported by U.S. Public Health Service-National Institutes of Health Grant NS.09199 and grant (RR-51) from the General Clinical Research Center Program of the Division of Research Resources. National Institutes of Health.

\section{REFERENCES}

BARBEAU, A., GILLO-JOFFROY, L., BOUCHER, R., NOWACZYNSKI, W., and GENEST, J. (1969). Renin-aldosterone system in Parkinson's disease. Science 165 , 291-292.

BELL, C., LANG, W.L. (1973). Neural dopaminergic vasodilator control in the kidney. Nature New Biol. 246, 27-29.

DAVIS, B.B., WALTER, M.J., and MURDAUGH, H.V. (1968). The mechanism of the increase in sodium excretion following dopamine infusion. Proc. Soc. Exp. Biol. Med. 129, 210-213.

EBLE, J.N. (1964). A proposed mechanism for the depressor effect of dopamine in the anesthetized dog. J. Pharmacol. Exp. Ther. $145,64-70$

FINLAY, G.D., WHITSETT, T.L., CUCINELL, E.A., and GOLDBERG, L.I. (1970). Cardiac and renal effects of L-dopa in patients with Parkinson's disease and congestive heart failure. Circulation 42 (Suppl. III), 109.

FINLAY, G.D., WHITSETT, T.L., CUCINELL, E.A., and GOLDBERG, L.I. (1971).
Augmentation of sodium and potassium excretion, glomerular filtration rate, and renal plasma flow by levodopa. New Eng. J. Med. 284, 865-870.

GOLDBERG, L.I.. McDONALD, JR., R.H., ZIMMERMAN, A.M. (1963). Sodium diuresis produced by dopamine in patients with congestive heart failure. New Eng. J. Med. 269, 1060-1064.

GOLDBERG, L.I. and WHITSETT, T.L. (1971). Cardiovascular effects of levodopa. J. Amer. Med. Assoc. 218, 1921-1923.

KATZ, F.H. and HOEHN, M.M. (1977). Effects of levodopa on the renin-aldosterone system. Clin. Pharmacol. Therapeutics 21, 388-391.

KEENAN, R.E. (1970). The Eaton collaborative study of levodopa therapy in parkinsonism: a summary. Neurol. (Minneap.) 20, Part 2, 46-59.

McDONALD, JR., R.H., GOLDBERG, L.I., MCNAY, J.L., and TUTTLE, JR., E.P. (1964). Effects of dopamine in man: Augmentation of sodium excretion, glomerular filtration rate, and renal plasma flow. $J$. Clin. Invest. 43, 1116-1124.

McNAY, J.L., McDONALD, JR., R.H., and GOLDBERG, L.I. (1965). Direct renal vasodilation produced by dopamine in dogs. Circ. Res. 16, 510-517.

McNAY, J.L., McDONALD, JR., R.J., and GOLDBERG, L.I. (1966). Comparison of the effects of dopamine, isoproterenol, norepinephrine, and bradykinin on canine renal and femoral blood flow after POB. J. Pharmacol. Exp. Ther. ISI, 23-3I.

MEYER, M.B., MCNAY, J.L., and GOLDBERG, L.l. (1967). Effects of dopamine on renal function and hemodynamics in the dog. J. Pharmacol. Exp. Ther. 156, 186-192.

MICHELAKIS. A.M. and ROBERTSON, D. (1970). Plasma renin activity and levodopa in Parkinson's disease. J. Amer. Med. Assoc. 213. 83-85.

NEEDLEMAN, P., DOUGLAS, JR., J.R. JAKSCHIK, B.. STOLCKLEIN, P.B., and JOHNSON, JR., E.M. (1974). Release of renal prostaglandin by catecholamines: relationship to renal endocrine function. J. Pharmacol. Exp. Ther, 188, 453-460.

RAPPELli, A., GLORIOSO, N., TEDDE, R. DESSI'FULGHERI, P., and MONACO. F. (1978). Effects of levodopa alone and in combination with dopadecarboxylase inhibitors on plasma renin activity in patients with Parkinson's disease. J. Neurol. Neurosurg. Psychiat. 41, 915-918.

SULLIVAN, J.M., NAKANO, K.K., and TYLER, H.R. (1973). Plasma renin activity during levodopa therapy. J. Amer. Med. Assoc. 224, 1726-1729.

WHITSETT, T.L., McKINNEY, A.S., and GOLDBERG, L.1. (1970). Tolerance to the cardiac effects of $\mathrm{L}$-dopa in patients with Parkinson's disease. Clin, Res. 18, 28. 